\title{
ASPHYXIA DUE TO REDUCED OXYGEN CONTENT IN THE ENVIRONMENT
}

\section{Yekhalov V. V., Khobotova N. V.}

\section{INTRODUCTION}

Asphyxia due to reduced oxygen content in the inhaled air is rare. However, the media fairly regularly inform the population about its episodes in wine vaults, silo pits, and in children - in enclosed spaces. Quite a serious problem is the exogenous hypoxia in miners as a result of accidents with the release of mine gas, in submarine crews - poisoning with carbon dioxide in case of failure of ventilation systems. Modern "extreme sport lovers" who are actively involved in mountain climbing and mountaineering, speleology and spelestology (including digging), amateur piloting of sports airplanes and aerostats, diving, etc., are subject to such lesions. In available special literature sources on the subject "Asphyxia due to reduced oxygen content in the environment" there are almost no reports related to intra-vitam pathogenetic features, diagnosis and the basics of providing medical care to asphyxia victims. There are few recommendations on the provision of medical care for mountain sickness, while other options for exogenous asphyxia are considered only from the perspective of a forensic medical examination, in most cases - postmortem. On the basis of individual domestic and foreign research works, personal theoretical and clinical experience, we developed an algorithm for diagnosis and medical care at the stages of the route of a victim with exogenous hypoxia.

The cause of exogenous type hypoxia is a decrease in the partial pressure of oxygen $\left(\mathrm{pO}_{2}\right)$ in the inhaled air. If this type of hypo oxygenation develops under normal barometric pressure, it is defined as normobaric exogenous hypoxia; in decrease in barometric pressure, it is called hypobaric exogenous hypoxia.

Pathogenesis of exogenous types of hypoxia:

Arterial hypoxemia is the initial and main component of exogenous hypoxia. It leads to a decrease in oxygen saturation of hemoglobin, total oxygen content in the blood and to impaired gas exchange and metabolism in the tissues.

Hypocapnia (respiratory alkalosis) occurs as a result of compensatory hyperventilation of the lungs caused by hypoxemia.

Arterial hypotension in combination with tissue hypoperfusion is largely a consequence of hypocapnia. 
Carbon dioxide is one of the main factors regulating the tone of cerebral vessels. Lowering its partial tension in arterial blood stimulates occlusion of the lumen of cerebral and heart arterioles, reducing their blood supply.

Deficiency of biological oxidation is the reason for activation of mechanisms of an emergent adaptation of the body to hypoxia. This is manifested by a decrease in the content of ATP in the cells, which is necessary to ensure the optimal level of vital activity and plastic processes.

A key component of an emergency adaptation of the body to hypoxia is the activation of mechanisms of $\mathrm{O}_{2}$ transport and substrates of metabolism to the tissues and organs.

Activation of the oxygen transport system and substrates of metabolism to the cells is accompanied by an intensive consumption of energy substrate. This can be a limiting factor in the degree and duration of hyperactivity of the body's transport systems.

Metabolic disorders in hypoxia:

Concentrations of ATP and creatine phosphate during hypoxia are progressively decreasing due to inhibition of biological oxidation processes (especially aerobic ones) in combination with rephosphorylation of adenosine monophosphate (AMP) and adenosine diphosphate (ADP).

The content of inorganic phosphate in the tissues increases due to the activation of the hydrolysis of ATP, ADP, AMP, creatine phosphate, as well as changes in the processes of oxidative phosphorylation.

Tissue respiration in the cells is inhibited due to a deficiency of oxygen and substrates of metabolism, as well as due to a decrease in the activity of enzymes of tissue respiration.

At the initial stage of hypoxia, glycolysis is activated, in the increase in the degree of hypoxia and metabolic acidosis, it is suppressed.

The biosynthesis of nucleic acids and proteins during hypoxia is reduced due to energy deficiency.

Proteolysis is enhanced due to stimulation of proteases under conditions of acidosis and non-enzymatic hydrolysis of protein molecules, nitrogen balance becomes negative (increase in the level of residual nitrogen in blood plasma and ammonia in tissues).

Lipolysis is activated as a result of increased lipase activity, lipid resynthesis is suppressed due to a deficiency of macroergic compounds; in blood plasma, intercellular fluid and cells there developsn excess of ketone bodies (acetoacetic and $\beta$-hydroxybutyric acids, acetone) and fatty acids. Higher fatty acids exert a dissociative effect on oxidation and phosphorylation, this increases ATP deficiency.

Water-electrolyte metabolism in tissues during hypoxia is significantly impaired due to ATP deficiency, the energy of which is necessary for the activity of ATPases $\left(\mathrm{Na}^{+}, \mathrm{K}^{+}\right.$-ATPase, $\mathrm{Ca}^{2+}$-dependent ATPase, etc.). 
Damage to membranes and their ion channels, which ensure their energy and electro-dependent transport, passive ion transport including;

Changes in hormones in the body that regulate the metabolism of mineral-corticoids, calcitonin, etc. ${ }^{1}$

In hypoxia, disorders of the functions of organs and tissues are expressed differently. This is determined by their different resistance to hypoxia, the rate of its development, the degree and duration of impact on the body. Tissue of the nervous system has the least resistant to hypoxia.

\section{Clinical forms}

Hypobaric hypoxia is a symptom complex resulted from a decrease in the partial pressure of oxygen in the inhaled air during high altitudes climbing. It occurs due to a deficiency in the concentration of oxygen in the inhaled air, against the background of a decrease in atmospheric pressure, when a person climbs up to an altitude of more than 3000-3500 m (where $\mathrm{pO}_{2}$ of air is reduced to approximately $100 \mathrm{~mm} \mathrm{Hg}$ ).

Subdivided into:

1) altitude sickness, which develops in aviators;

2) mountain (alpine) sickness, in the development of which such additional factors as physical fatigue, cooling, ionized air and ultraviolet radiation play a role.

Relevance of the topic - actually altitude sickness occurs in aviators when aircraft with an unpressurized cabin marches a height limit of 7,000 meters. Mountain (alpine) sickness is a problem of members of climbing expeditions. It occurs in about $25 \%$ of people who have climbed to a height of more than $2500 \mathrm{~m}$ above sea level, in $75 \%$ of people crossing a height of $4500 \mathrm{~m}$. Death rate on the Everest exceeds 3\%, the leading cause of mortality is mountain sickness. Disability in severe mountain sickness reaches $42 \%{ }^{2}$.

\subsection{Altitude sickness}

Causes: a quick altitude gain by balloons and zeppelins with unpressurized nacelles (above $2000 \mathrm{~m}$ ), aircrafts with an unpressurized cabin (7000 m): a drop in oxygen content in the inhaled air and a sharp decrease in atmospheric pressure (the release of gases dissolved in biological fluids "boiling" in severe cases).

\footnotetext{
${ }^{1}$ Литвицкий П.Ф. Гипоксия. Вопросы современной педиатрии. 2016. Т. 15. № 1. C. 45-58. DOI 10.15690/vsp.v15i1.1499.

${ }^{2}$ Полутова Н.В., Чеснокова Н.П., Понукалина Е.В., Бизенкова М.Н. Лекция 12. Асфиксия: стадии нарушения внешнего дыхания, механизмы развития. Научное обозрение. Медицинские науки. 2017. № 2. C. 57-60. URL: https://science-medicine.ru/ ru/article/view?id=981 (дата обращения: 04.01.2020).
} 


\section{Clinical signs:}

1) fatigue, indifference to the environment, sometimes drowsiness, dizziness, weakness of memory, dyspeptic disorders (sometimes an excited state which resembls alcoholic intoxication is observed);

2) acceleration and deepening of breathing, tachycardia, hypertension, inhibition of peripheral circulation (cyanosis), gradual dysfunction of higher nervous activity: stimulation of the site of locomotor center (tremors, clonic convulsions), complete loss of orientation, loss of consciousness, sometimes with severe symptoms of cardiovascular collapse (pallor, cold sweat, threadlike slow pulse, drop in blood pressure);

3 ) the symptom complex of cardiovascular collapse occurs suddenly; sometimes a collaptoid state is preceded by bradycardia - a symptom of approaching a "critical height" (in this period blood pressure may be increased as compared to the initial level);

4) sensations of pain in the frontal, maxillary cavities;

5) very severe pain in the ears (especially in the catarrhal state of the Eustachian tubes), in the area of the mastoid process and poorly sealed teeth;

6) severe joint pain;

7) pain behind the breastbone;

8) cough with albuminous sputum.

Treatment:

1) trendelenburg position or on the left side with a raised leg end;

2) oxygenation through a mask of $6-8 \mathrm{l} / \mathrm{min}$;;

3) dexamethasone, $8 \mathrm{mg}$ intramuscularly;

4) acetazolamide (diacarb) orally $125-250 \mathrm{mg} 3$ times a day;

5) in systolic blood pressure above $90 \mathrm{~mm} \mathrm{Hg}$. - nifedipine - $30 \mathrm{mg}$ orally twice a day; or nitroglycerin 1 tablet under the tongue (in 20 minutes, not more than 3 times);

6) lipostabil (or Essentiale) 60-80 $\mathrm{ml}$ intravenously (prevention and treatment of air embolism).

HBO technique: $1.5 \mathrm{~atm}$ (altitude sickness of moderate severity); $2.5 \mathrm{~atm}$ (severe altitude sickness) for 90 minutes. Duration of compression and decompression is $10-15$ minutes at a rate of 0.1 atm per minute ${ }^{3}$.

\subsection{Acute mountain sickness}

Acute mountain sickness (AMS) is observed with more or less pronounced physical exertion in climbing mountains on foot, where the body is exposed to low barometric pressure and reduced oxygen content in the

${ }^{3}$ Никонов В.В., Савицкая И.Б., Нудьга А.Н., Киношенко Е.И., Ковалева В.В., Павленко А.Ю. Постгипоксическая энцефалопатия: возможности коррекции. Медицина неотложных состояний. 2008. № 4(17). С. 65-71. 
inhaled air, cooling, increased insolation, and other conditions of mid- and highlands. In freezing temperature, a breath is usually short, it also enhances hypoxia. In the cold the permeability of the cellular walls is disrupted, which leads to additional tissue edema.

In hypoxic hypoxia, the oxygen tension in arterial blood, the saturation of hemoglobin with oxygen and its total content in the blood decreases. Hypocapnia which develops due to compensatory hyperventilation of the lungs can also have a negative effect. Severe hypocapnia leads to impairment of cerebral blood supply ant that of the heart (vasoconstriction), respiratory alkalosis. Respiratory alkalosis is compensated by increased excretion of the bicarbonate anion by the kidneys; the sodium content in the body decreases, which results in a decrease in the volume of extracellular fluid up to hypovolemia, the electrolyte balance is disturbed. In these cases, the addition of small amounts of carbon dioxide (carbogen) to the inhaled air to eliminate hypocapnia can significantly alleviate the condition.

Mild degree:

1) symptoms appear within 6-12 hours;

2) feeling unwell, loginess, malaise, palpitation, mild dizziness, shortness of breath on physical exertion, drowsiness and, at the same time, poor sleep onset;

3) high-altitude headache, defined by the International Headache Society, is a condition that occurs within 24 hours after climbing above 2500 meters and ceases within 8 hours after descent of the mountain;

4) in 3-4 days all these phenomena usually disappear, if you do not climb higher.

Moderate degree:

1) at a height of 2500-3500 m signs of euphoria develop: high spirits, excessive gesticulation and talkativeness, accelerated speech tempo, purposeless fun and laughter, carefree, frivolous attitude to the environment, hereinafter - apathy, melancholy, loss of interest to the environment;

2) at a height of 4000-5000 m moderate or severe headache develops, restless, broken sleep, with unpleasant dreams, frequent awakening from shortness of breath is noted;

3) on physical effort breathing and palpitations immediately increase, dizziness appears, appetite decreases, nausea, vomiting appears, dry throat causes thirst;

4) nosebleeds, cyanosis of the lips is possible.

Severe degree:

1) at a height of 5000-7000 $\mathrm{m}$ and higher, general weakness, fatigue, whole body heaviness develops; 
2) moderate dizziness and at times severe headache, on sudden movements - "breath of a chased dog", palpitation, insomnia, severe dry throat, dry cough, anorexia, nausea, vomiting, constipation, abdominal bloating;

3) pale or cyanotic skin; elevation of body temperature by $1-2{ }^{\circ} \mathrm{C}$, nose and gastric bleedings, hemoptysis;

4) symptoms of high-altitude pulmonary edema (progressive dyspnea, cough, hypoxia, weakness) appear on the day 2-3 at a high altitude, due to the movement of fluid from the capillaries to the alveoli;

5) high-altitude cerebral edema is an extreme manifestation of acute mountain sickness.

\subsection{Treatment of acute mountain sickness}

Mild or moderate degree:

1) rest;

2) liquids (juices, tea);

3) non-narcotic analgesics (paracetamol);

4) medicines for nausea (aeron, metoclopramide);

5) acetazolamide (diacarb) 125-250 mg twice a day for 3 days;

6) ondansetron $4 \mathrm{mg}$ iv, im or sublingually every 6 hours in vomiting;

7) dexamethasone $2 \mathrm{mg}$ every 6 hours or $4 \mathrm{mg}$ every 12 hours, very high doses ( $4 \mathrm{mg}$ every 6 hours) can be considered in situations of very high risk, such as military operations or the search for missing people;

8) budesonide 200 micrograms inhaled twice daily was effective in preventing AMS as compared with placebo;

9) ibuprofen $600 \mathrm{mg} 2$ times a day or acetaminophen $1000 \mathrm{mg} 2$ times a day.

Severe degree:

1) immediate descent down;

2) bring to a semi-sitting position;

3) narcotic analgesics, alcohol, salicylates are contraindicated;

4) treatment should be started with dexamethasone and oxygen inhalation sufficient to achieve $\mathrm{SpO}_{2}>90 \%$;

5) oxygen therapy (preferably carbogen) through the mask (in field studies, increased arterial oxygen saturation quickly reduces the symptoms of the disease);

6) portable oxygen concentrators can be charged with solar or hydroelectric energy, which allows their use in remote clinics or on large expeditions; the goal of oxygen therapy is to maintain $\mathrm{O}_{2}$ saturation above $90 \%$;

7) portable hyperbaric chambers - lightweight airtight bags that simulate descent, are currently used by many large expeditions: the victim is fastened 
in a bag, air pressure inside the bag is increased with the help of a foot or hand pump; pressurization in the bag at a level of 200 mbar simulates a descent to a height of $2000 \mathrm{~m}$; each patient placed in the bag should be able to protect his/her external airways and equalize pressure in the middle ear;

8) acetazolamide (diacarb) $125-250 \mathrm{mg}$ twice a day for 3 days;

9) dexamethasone $8 \mathrm{mg}$ orally (preferably intramuscularly), then $4 \mathrm{mg}$ every 6 hours within 24 hours;

10) reduce the temperature to $37^{\circ} \mathrm{C}$ (paracetamol orally, not more than 4.0 within 24 hours);

11) provide intravenous access, administer infusion solutions with a bolus, in the future, the volume of infusion should be maintained at $125 \mathrm{ml} /$ hour in order to maintain systolic blood pressure above $90 \mathrm{~mm}$;

12)in stabilized blood pressure - nifedipine $-30 \mathrm{mg}$ orally twice a day or nitroglycerin 1 tablet under the tongue (20 minutes after, not more than 3 times);

13) apply venous tourniquets to the hips and shoulders for 12 hours;

14)intravenous solution of aminophylline $2.4 \%-10 \mathrm{ml}$;

15)breathing through a tissue soaked in ethyl alcohol;

16) tadalafil $10-20 \mathrm{mg}$ twice a day and sildenafil $20 \mathrm{mg}$ three times a day is effective to prevent edema;

17)in a randomized, placebo-controlled study, the selective $\beta$-agonist salmeterol (125 mg twice a day) reduced the incidence of high-altitude pulmonary edema;

18)in in-patient setting when the preservation of consciousness does not play a role, morphine should be used to reduce pressure in the pulmonary artery.

Do not use more than 1 vasodilator simultaneously.

The use of furosemide (lasix) in high altitude conditions is not recommended, since with reduced atmospheric pressure it does not reduce cerebral edema during hypoxia.

Prevention of mountain sickness:

1. "The Wilderness Medical Society" recommends climbers and mountain tourists who travel more than 3,000 $\mathrm{m}$ above sea level to climb not more than $300 \mathrm{~m}$ per day, with a day of rest for every 1,000 meters.

2. Artificial increase in oxygen by $6 \%$ in the premises of high-altitude weather stations and observatories.

3. Hypoxic tents can be used to facilitate acclimatization and to prevent AMS, provided that sufficiently long workouts will be held regularly during the number of weeks, which correspond to the altitude of ascent.

4. Administration of ascorbic acid $(500 \mathrm{mg})$, tocopherol acetate $(200 \mathrm{mg})$ and lipoic acid $(300 \mathrm{mg}$ ) orally 2 times a day 3 weeks before climbing to the highlands and for 10 days at altitude. 


\subsection{Asphyxia in enclosed or semi-enclosed space}

Normobaric exogenous hypoxia is a type of mechanical asphyxia that develops due to the restriction of oxygen with air into the body at normal barometric pressure.

Relevance of the topic: asphyxia in a confined space is a rare variant of hypoxic / hypercapnic damage. Asphyxia in a semi-enclosed space occurs in industrial conditions in $62 \%$, in maintenance activities - in $13 \%$, in laboratories, medical institutions and transport - in 6\%, the causes are not identified - in $14 \%$ of cases. Mining workers, submarine crews, divers, etc. are at risk of normobaric exogenous hypoxia. Methods of using narcotic and toxic substances, which were widespread in the nineties of the last century, cause critical conditions or death of at least $20 \%$ of drug users and substance abusers ${ }^{4}$.

Causes of asphyxia in a closed space:

1. Improper childcare: self-closing in refrigerators produced until the 90s of the last century (such as "Dnepr", "Donbass", "Kristall" and others that cannot be opened from the inside), washing machine's drums, safes, cabinets, chests, airtight container, etc.

2. Children's games (for the same reason) "in astronauts" with a plastic bag placed on the head, which, with the development of hypoxia, the child cannot remove on his own.

3. Addiction and substance abuse: placing the head in a plastic bag with the active substance.

4. Accidental (or intentional) closing of people in freezers, autoclaves, industrial mixers, pump compartment (reactor).

5. Sexual perversions: asphyxiophilia, scarfing.

6. Faults of aqualungs, gas mask sets.

7. Failure of air support devices of submarines, bathyscaphes, in the compartments of ships, in the premises of tankers.

8. Disorder of air regeneration and / or oxygen supply for breathing in aircraft and in-depth vehicles, autonomous suits (astronauts, pilots, divers, rescuers, firefighters).

9. In case of malfunctions and failure of medical breathing equipment, pressure chambers.

10. In case of non-compliance with ventilation techniques.

${ }^{4}$ Калинина, Е.Ю. Судебно-медицинская экспертиза отравлений бытовым газом (экспериментально-клиническое исследование) : автореф. дисс. на соискание учен. степени докт. мед. Наук : 14.03.05. Санкт-Петербург, 2017. 38 с. URL: https://www.forens-med.ru/book.php?id=5201. 
11. Emboulments and landslides in quarries, in mines, in underground utilities.

12. Criminal acts for the purpose of murder or torture ("playing a diver"): putting a plastic bag or gas mask on the victim's head with a blocked intake of filtered air.

13. Asphyxia during burial in an avalanche is characterized by oxygen deficiency and hypercapnia due to repeated inhalation of exhaled air.

14. Non-avalanche snow burial (NASB), which is also called the "snow immersion of non-avalanche etiology".

Examples of objects where asphyxia develops in semi-enclosed space:

1. Bunkers, boilers, lift shafts, inspection holes (sewer, storm, power supply, etc.), tanks, incinerator units, scrubbers (wet dust collectors), sewer communications, transformer arches, pump stations, air heaters, mines, cellars, basements.

2. Semi-enclosed space can be formed by temporary fences (plastic, tarpaulin coatings to protect against natural factors and / or preservation of buildings and structures).

3. Indoors during a fire, when oxygen is intensively consumed, its deficiency may be one of the factors of damage, the effect of which is enhanced due to the formation of toxic combustion products.

4. When heating the room with open gas hobs.

5. Carbon dioxide can accumulate in mines, wells, vegetable stores, silo pits and cesspools, wine cellars with deoxygenation.

6. Corrosion (rust), fermentation or other forms of oxidation absorb oxygen, which creates a hazard in unventilated rooms.

7. Staying in the atmosphere polluted by mine (colliery) gas.

8. Staying near nitrogen plants with massive gas discharge in a short time, leakage from compressed nitrogen bottles.

The mechanisms of damage in asphyxia in a closed / semi-enclosed space are characterized by a combination of hypercapnia, hypoxia, hypoxemia (table 1).

It develops in cases where the total barometric pressure is normal, but the partial pressure of oxygen in the inhaled air is lowered. In these cases, hypoxia can be combined with hypercapnia. Moderate hypercapnia has a beneficial effect (increased blood supply to the brain and heart). Significant hypercapnia is accompanied by acidosis, ion disbalance, decrease in oxygen saturation of arterial blood.

Criteria for hypoxic hypoxia: decrease in $\mathrm{pO}_{2}$ in the inhaled air, decrease in $\mathrm{pO}_{2}$ in the alveolar air, decrease in content and tension of oxygen in arterial blood; hypocapnia, which is replaced by hypercapnia, a decrease in the total air-venous gradient of $\mathrm{pO}_{2}$. 
Clinical manifestations and consequences of decrease in oxygen content in the air $^{5}$

\begin{tabular}{|c|c|l|}
\hline $\begin{array}{c}\text { Oxygen } \\
\text { content } \\
\text { in the air, } \%\end{array}$ & $\begin{array}{c}\text { Exposure } \\
\text { time }\end{array}$ & \multicolumn{1}{|c|}{$\begin{array}{c}\text { Clinical manifestations } \\
\text { and consequences }\end{array}$} \\
\hline $20,9 \%$ & Constantly & \multicolumn{1}{c|}{ Normal health } \\
\hline $19,5 \%$ & Constantly & $\begin{array}{l}\text { Established minimum of concentration } \\
\text { for a human (US OSHA) }\end{array}$ \\
\hline $15-19,5 \%$ & $\begin{array}{c}\text { During } \\
24 \text { hours }\end{array}$ & $\begin{array}{l}\text { Work decrement: early symptoms in } \\
\text { people with circulatory problems and } \\
\text { cardiopulmonary diseases }\end{array}$ \\
\hline $12-15 \%$ & $\begin{array}{l}\text { In } \\
\text { Abnormal fatigue during physical } \\
\text { exertion, emotional disturbance, } \\
\text { tachycardia, tachypnea, impaired } \\
\text { thinking and attention, decreased } \\
\text { coordination, limited ability to } \\
\text { objectively assess the situation }\end{array}$ \\
\hline $10-12 \%$ & $\begin{array}{c}\text { In } \\
1-3 \text { minutes }\end{array}$ & $\begin{array}{l}\text { Further increase in heart rate and } \\
\text { respiration, dizziness, mental } \\
\text { deficiency, cyanosis of lips }\end{array}$ \\
\hline $8-10 \%$ & $\begin{array}{c}\text { In } \\
1 \text { minute }\end{array}$ & $\begin{array}{l}\text { Nausea, vomiting, cramps, loss of } \\
\text { consciousness }\end{array}$ \\
\hline $4-6 \%$ & $\begin{array}{c}\text { Up to } \\
1 \text { minute }\end{array}$ & $\begin{array}{l}\text { Coma in 40 seconds, convulsions, } \\
\text { respiratory arrest, death }\end{array}$ \\
\hline
\end{tabular}

Peracute form of asphyxia develops when breathing with pure nitrogen or inert gases (helium, argon, etc.). In such cases, loss of consciousness and death occurs within 45 to 90 seconds. According to the US government's Chemical Safety and Accident Investigation Commission, between 1992 and 2002, 80 deaths from nitrogen asphyxiation were recorded in the United States in the enterprises, as well as in medical and scientific institutions. In 2015, the Oklahoma governor was the first to sign a bill to legalize execution of the convicted persons in a gas chamber using gaseous nitrogen.

5 Витер В.И., Вавилов В.И., Кунгурова В.В., Бабушкина К.А. Механическая асфиксия: судебно-медицинская диагностика и оценка : учебное пособие. Ижевск, 2016. $86 \mathrm{c}$. 
Carbon dioxide (carbon dioxide, $\mathrm{CO}_{2}$ ) - under ordinary conditions, a colorless gas with a slightly sour smell and taste, it is soluble in water and does not burn. This gas is slightly toxic, being a natural stimulant of the respiratory center. The specific gravity of $\mathrm{CO}_{2}$ is 1.53 , i.e. it is one and a half times heavier than air, so it can appear not only in the workings where the fire happened, but also in the workings located below, as well as along the path of the ventilation stream. Carbon dioxide in the mine is usually formed during decay of the lining material, in mycotic contamination of drives resulted from a slow oxidation of coal, it is released directly from rocks and coal. A secondary source of $\mathrm{CO}_{2}$ formation is people's breath and blastings.

There are areas on the inflactions of the Earth's crust characterized by plentiful vegetation. The size of plants in such places significantly exceeds those of ordinary representatives of the flora. This is due to the fact that carbon dioxide accumulates at the bottom of these wind-blown hollows, stimulating enhanced growth of grass and shrubs. In "carbon dioxide" or "damn places" you can observe a large number of skeletons and corpses of representatives of the local fauna: rank vegetation attracts small animals by the abundance of food and shelters, and predators run there, hunting them. Cases of losses of life in such places are known. More often they are newcomers who are tempted to rest in a green oasis. A person can stay in such a place for a long time without damage to health, if the gas level is below his/her respiratory tract, but if a person sits or lies down, then the result will be tragic. High concentrations of carbon dioxide caused mass deaths of people who lived near volcanoes. Lakes Nios and Kivu were formed in craters formed by "dormant" volcanoes in Africa. Cracks and springs under the craters feed the lakes and deliver high concentrations of carbon dioxide that have poisoned entire villages. Locals call these odorless carbon dioxide clouds "mazuku", which means "evil wind". Children are more often become victims because of their short stature they breathe air closer to the ground. In Italy, there is the "Dog Cave" ("Grotta del Cane") - a small karst formation in the eastern part of the Phlegreian fields near Naples. Inside the cave is fumarola, which rejects carbon dioxide of volcanic origin. This is a famous attraction for tourists of the Grand Tour. Carbon dioxide is heavier than air, so it accumulates in the deep parts of the cave, a person in an upright position does not feel any discomfort but and a dog dies.

Except in severe cases, carbon dioxide poisoning usually goes away without consequences as soon as the victim begins to breathe normal atmospheric air.

According to current standards, the $\mathrm{CO}_{2}$ content in functioning mine workings should not exceed $0.5 \%$, in the outgoing mine stream $-0.75 \%$, while conducting and restoring mine workings in pot-outs $-1 \%$. 
Signs of poisoning with carbon dioxide depending on its concentration in the inhaled air

\begin{tabular}{|c|c|l|}
\hline $\begin{array}{c}\text { Carbon } \\
\text { dioxide } \\
\text { content } \\
\text { in the air,\% }\end{array}$ & $\begin{array}{c}\text { Exposure } \\
\text { time }\end{array}$ & \multicolumn{1}{|c|}{$\begin{array}{c}\text { Signs of poisoning } \\
\text { and consequences }\end{array}$} \\
\hline $1-1,5 \%$ & Constantly & $\begin{array}{l}\text { Does not cause pathological effects } \\
\text { on humans }\end{array}$ \\
\hline $2-2,5 \%$ & $\begin{array}{c}\text { For several } \\
\text { hours } \\
\text { (up to 8 hours) }\end{array}$ & $\begin{array}{l}\text { Breathing accelerates without } \\
\text { noticeable effects }\end{array}$ \\
\hline $3-5 \%$ & $\begin{array}{c}\text { About } \\
20 \text { minutes }\end{array}$ & $\begin{array}{l}\text { Rate and depth of breathing increases, } \\
\text { tinnitus, sensible pulsation of blood } \\
\text { in the temples, shortness of breath } \\
\text { and general weakness are noted }\end{array}$ \\
\hline $5,5-8 \%$ & $5-15$ minutes & $\begin{array}{l}\text { Severe headaches, dizziness, general } \\
\text { malaise, fainting, loss of consciousness }\end{array}$ \\
\hline $\begin{array}{c}\text { More than } \\
10 \%\end{array}$ & $1-2$ min & Loss of consciousness, death \\
\hline
\end{tabular}

Methane is an inert compound from the group of paraffin hydrocarbons, can cause poisoning only in a very high concentration, or under high barometric pressure (due to the low solubility of methane in water and blood). $\mathrm{CH}_{4}$ is a gas without color, odor and taste, slightly soluble in water. The relative density of methane is 0.554 , i.e. almost 2 times less than air density, therefore, rejecting from the coal layer and often from the surrounding rocks, with insufficient ventilation, it accumulates in the upper part of the workings.

A two-phase effect of methane on the central nervous system was revealed: after the initial excitation, inhibition occurs. Inhaling a mixture of methane and atmospheric air (1: 1) for 20-40 minutes did not lead to the death of experimental animals, in which only an increase in blood $\mathrm{pH}$ and a decrease in saturation of arterial blood with oxygen from 91.6 to $65.2 \%$ were observed. The accumulation of methane in the air to $25-30 \%$ which corresponds to a decrease in oxygen content from 21 to $15-16 \%$, is accompanied by distinct signs of oxygen deficit, while there is an increase in heart rate, in breathing volume, inattention and motor dysfunction. When the concentration of natural gas in the atmosphere is $80-90 \%$, after 5-6 breaths a person begins to lose consciousness with the disappearance of all reflexes. 
Sudden methane outbursts in coal mines lead to the development of acute oxygen deficit, which is characterized by complaints of headache, dizziness, nausea, vomiting, general weakness, pain in the heart. In a mild hypoxia, not accompanied by loss of consciousness (or with a short-term loss), symptoms of functional disorders of the nervous system are detected by the type of neurasthenia ( $80 \%$ of cases), hysteria (11\%), and reactive psychosis $(2.4 \%)$. In a moderate and severe hypoxia, when loss of consciousness lasts from several hours to a day or more, scleral hemorrhages, symptoms of organic damage to the nervous system with functional insufficiency of the cranial nerves, anisoreflexia, hyporeflexia or disappearance of the abdominal reflexes, decrease or increase in myogenic tonus, onset of pathological reflexes are observed. Due to the development of myocardial hypoxia, such signs of marked weakening of cardiac activity as muffled heart sounds, tachycardia, hypotonia are noted, signs of hypoxia on the ECG are observed. Severe damage to the nervous system caused by lingering course of hypoxic coma, disorder of redox processes are of great danger . $^{6}$

The main clinical signs:

1. Tachypnea, shortness of breath.

2. Palpitation.

3. Rapid loss of consciousness, hypoxic cerebral edema.

4. Cough, pulmonary edema.

5. Plethora and hemorrhages in various organs and tissues.

According to regulatory documents, the maximum permissible content of methane in the air outgoing from a mine or wing of the air flow is $0.75 \%$; in a return air from a site of stope ore and advanced workings - up to 1\%; in the fresh air entering the stope ores and development headings - up to $0.5 \%$. The concentration of local accumulations of methane in stope ores and advanced workings should not reach $2 \%$ for a short time.

Filling the workings with methane during sudden coal and gas outbursts dramatically reduces the oxygen content in the mine air and makes it unfit to breath. Therefore, methane is considered to be asphyxiation gas. So, if it is present in the air at a concentration of $24 \%$, breathing is markedly difficult, and at $43 \%$ the oxygen content reaches $12 \%$. Inhaling air containing $50-80 \%$ of methane in a normal amount of oxygen causes severe headache and drowsiness. The minimum allowable volumetric fraction of oxygen in mine air is $20 \%$.

${ }^{6}$ Tilburg, C.V., Grissom, C.K., Zafren, K., et al. Wilderness Medical Society Practice Guidelines for Prevention and Management of Avalanche and Nonavalanche Snow Burial Accidents. Wilderness \& Environmental Medicine. 2017. Vol. 28. Issue. 1. P. 23-42. URL: https://doi.org/10.1016/j.wem.2016.10.004. 
Medical care at the pre-hospital stage:

1. Recovery of victims from enclosed / semi-enclosed spaces.

2. Carrying out of /evacuation of victims from the foci of the atmosphere with a low oxygen content, a very high content of nitrogen, carbon dioxide, methane, etc. 3 . If necessary, artificial pulmonary ventilation (APV), tracheal intubation.

3. If $\mathrm{HBO}$ is not possible, inhalation through the face mask of $100 \%$ moistened oxygen in the first hour, reducing the concentration of $\mathrm{O}_{2}$ in the following hours by $20 \%-30 \%$ until the normal atmospheric content is reached.

4. In persistent hypotension (blood pressure system. $<90 \mathrm{~mm} \mathrm{Hg}$ ) dopamine infusion at a rate of $10-15 \mathrm{mcg} / \mathrm{kg} / \mathrm{min}$.

5. Decongestant and dehydration therapy: infusion therapy is limited to 400-600 $\mathrm{ml}$ (glucose solutions are contraindicated), dexamethasone or betamethasone (betaspan) up to $12 \mathrm{mg}$ iv, furosemide (in hyper- and normotension) 2-4 $\mathrm{ml}$ of $1 \%$ solution or torasemide (torside) $20 \mathrm{mg}$ iv.

6. In excitation or convulsive readiness - diazepam (sibazon) $0.5 \%$ $2.0 \mathrm{ml}$ iv.

Qualified medical assistance:

1. In the absence of adequate spontaneous breathing, APV continues in regimes that will allow maintaining normoxia and normocapnia.

2. In the absence of recovery of consciousness - carrying out hyperbaric oxygenation in the regime of up to $2.5 \mathrm{~atm}$. within 90 minutes, the duration of compression and decompression with 10-15 minutes each at a rate of 0.1 atm. per minute.

3. Infusion therapy in restrictive mode $(25-30 \%$ of the daily requirement).

4. In increasing pressure in the pulmonary artery (high central venous pressure), drugs that reduce the venous return to the heart (only in the absence of hypotension) are prescribed: nitroglycerin, theophylline (aminophylline) $2.4 \%-3 \mathrm{mg} / \mathrm{kg}$, antispasmodics, short-acting ganglion blockers.

5. Large doses of corticosteroids (800-1000 mg of hydrocortisone or 12-24 mg of dexamethasone, or 12-20 mg of betamethasone (betaspan), or 150-180 mg of prednisolone per day).

6. Furosemide (in hyper- and normotension) $4-8 \mathrm{ml}$ of a $1 \%$ solution or torasemide (torside) $4 \mathrm{ml}$ of a $0.5 \%$ solution intravenously.

7. In psychomotor agitation - sedative drugs: diazepam (sibazon) $0.5 \%-2-4 \mathrm{ml}$ (then $2 \mathrm{ml}$ iv until the effect is obtained) sodium oxybutyrate $20 \%-10-20 \mathrm{ml}$ iv by drop infusion in $0.9 \%$ solution of sodium chloride. 
8. Early administration of heparin (10,000 units per day) or enoxaparin (phlenox) $0.4 \mathrm{ml} \mathrm{s} / \mathrm{c}$ and antiplatelet agents (pentoxifylline $5-10 \mathrm{ml} 2 \%$ iv solution daily).

9. Antihypoxants administration: meldonium (vasopro, mildronate) $5.0 \mathrm{ml}$ iv, thiotriazolin $-2-4 \mathrm{ml}$ iv, ascorbic acid $-1-3 \mathrm{ml}$ of a $5 \%$ solution for intravenous drop infusion: a single dose is dissolved in $50-100 \mathrm{ml}$ of $0.9 \%$ sodium chloride solution and is administered by iv drop infusion slowly at a rate of 30-40 drops per minute.

10. Desapur at a dose of $10 \mathrm{mg} / \mathrm{kg}$ and mexidol at a dose of $100 \mathrm{mg} / \mathrm{kg}$ showed pronounced antihypoxic activity in case of hypercapnic hypoxia 2.35 and 2.29 times, respectively.

11. Intragastric and intestinal oxygenation.

12. Treatment of posthypoxic / postanoxic encephalopathy: citicoline (lira, neurocytin) $2000 \mathrm{mg}$ per $200 \mathrm{ml}$ of isotonic saline iv by drop infusion slowly (up to 20 drops per 1 minute) during 24 hours; $1000 \mathrm{mg}$ of choline alfoscerate in the first 14-20 days after an intravenous drop infusion 2-3 times a day; amantadine sulfate (PK-Merz) $200 \mathrm{mg} 2$ times a day, iv drop infusion during 5 days (the rate of administration of one vial is not less than 180 minutes).

\section{Complications}

1. Comatose states (depending on the degree of inhibition of brain functions and the level of regulation of preserved functions): state of decortication, subcortical coma; anterior-truncal (diencephalicmesencephalic), or "hyperactive" coma; posterior-truncal, or "flaccid" coma; terminal (irreversible) coma.

2. States of partial impaired consciousness: somnolentia; stupefaction; stupor.

3. Syndromes of diffuse organic damage: severe posthypoxic encephalopathy (with mnemonic, visual, cerebellar disorders); moderate posthypoxic encephalopathy; asthenic states (posthypoxic asthenia with the phenomena of hypo- and hypersthenia).

\section{CONCLUSIONS}

1. Proper looking after children and people with disabilities.

2. Compliance with safety standards and safety when working at industrial facilities, transport, in domestic conditions, in extreme sports and entertainment.

3. Never be alone in extreme conditions.

4. If it is impossible to leave the enclosed space, scatter lime on the floor (if any). 
5. Use an avalanche "airbag" - the only type of avalanche safety equipment that prevents burial.

6. If exposed to an avalanche, use an artificial air pocket device (AAPD), therewith exhaled air is vented into the space behind the victim.

\section{SUMMARY}

Quite a serious problem is the exogenous hypoxia in miners as a result of accidents with the release of mine gas, in submarine crews - poisoning with carbon dioxide in case of failure of ventilation systems. Modern "extreme sport lovers" who are actively involved in mountain climbing and mountaineering, speleology and spelestology. On the basis of individual domestic and foreign research works, personal theoretical and clinical experience, we developed an algorithm for diagnosis and medical care at the stages of the route of a victim with exogenous hypoxia. Hypobaric hypoxia is a symptom complex resulted from a decrease in the partial pressure of oxygen in the inhaled air during high altitudes climbing. It occurs due to a deficiency in the concentration of oxygen in the inhaled air, against the background of a decrease in atmospheric pressure, when a person climbs up to an altitude of more than 3000-3500 m. Subdivided into: altitude sickness and mountain (alpine) sickness. Asphyxia in enclosed or semi-enclosed space - normobaric exogenous hypoxia is a type of mechanical asphyxia that develops due to the restriction of oxygen with air into the body at normal barometric pressure. The mechanisms of damage in asphyxia in a closed / semi-enclosed space are characterized by a combination of hypercapnia, hypoxia, hypoxemia. Prevention: 1) proper looking after children and people with disabilities; 2) compliance with safety standards and safety when working at industrial facilities, transport, in domestic conditions, in extreme sports and entertainment; 3) never be alone in extreme conditions; 4) If it is impossible to leave the enclosed space, scatter lime on the floor (if any); 5) use an avalanche "airbag" - the only type of avalanche safety equipment that prevents burial; 6) if exposed to an avalanche, use an artificial air pocket device (AAPD), therewith exhaled air is vented into the space behind the victim.

\section{REFERENCES}

1. Литвицкий П.Ф. Гипоксия. Bопросы современной педиатрии. 2016. T. 15. № 1. C. 45-58. DOI: 10.15690/vsp.v15i1.1499.

2. Никонов В.В., Савицкая И.Б., Нудьга А.Н., Киношенко Е.И., Ковалева В.В., Павленко А.Ю. Постгипоксическая энцефалопатия: возможности коррекции. Медицина неотложных состояний. 2008. № 4(17). C. 65-71. 
3. Витер В.И., Вавилов В.И., Кунгурова В.В., Бабушкина К.А. Механическая асфиксия: судебно-медицинская диагностика и оценка : учебное пособие. Ижевск, 2016. 86 с.

4. Yanisko P., Kroll D. Use Nitrogen Safety. Chemical Engineering Progress. 2012. March. P. 44-48.

5. Muza S. R., Fulco C. S., Cymerman A. Altitude Acclimatization Guide. US Army Research Inst. of Environmental Medicine, Thermal and Mountain Medicine Division Technical Report USARIEM-TN-04-05. 2004. URL: http://archive.rubicon-foundation.org/7616.

6. Полутова Н.В., Чеснокова Н.П., Понукалина Е.В., Бизенкова М.Н. Лекция 12. Асфиксия: стадии нарушения внешнего дыхания, механизмы развития. Научное обозрение. Медицинские науки. 2017. № 2. C. 57-60. URL: https://science-medicine.ru/ru/article/view?id = 981 (дата обращения: 04.01.2020).

7. Механічна асфіксія / Волков О.О. та ін.; ред.: Л.А Дзяк, О.М. Клигуненко ; МОЗ України, ДЗ “Дніпропетр. мед. акад. МОЗ України”. Дніпро : Лipa, 2019. С. 105-120.

8. Yekhalov Vasiliy, Khobotova Nataliya. Obturative asphyxia // Development of modern science: the experience of European countries and prospects for Ukraine: monograph / edited by authors. 3rd ed. Riga, Latvia : "Baltija Publishing", 2019. P. 293-307.

9. Hohlrieder M., Brugger H., Schubert H.M. Pattern and Severity of Injury in Avalanche Victims. High Altitude Medicine \& Biology. 2007. Vol. 8, No 1. P. 56-61. URL: https://doi.org/10.1089/ham.2006.0815/.

10. Brugger H., Sumann G., Meister R. et al. Hypoxia and hypercapnia during respiration into an artificial air pocket in snow: implications for avalanche survival. Resuscitation. 2003. № 58(1). P. 81-88. URL: https://doi.org/10.1016/s0300-9572(03)00113-8/.

11. Tilburg, C.V., Grissom, C.K., Zafren, K., et al. Wilderness Medical Society Practice Guidelines for Prevention and Management of Avalanche and Nonavalanche Snow Burial Accidents. Wilderness \& Environmental Medicine. 2017. Vol. 28. Issue. 1. P. 23-42. URL: https://doi.org/10.1016/ j.wem.2016.10.004/.

12. Калинина, Е.Ю. Судебно-медицинская экспертиза отравлений бытовым газом (экспериментально-клиническое исследование) : автореф. дисс. на соискание учен. степени докт. мед. уаук : 14.03.05. Санкт-Петербург, 2017. 38 c. URL: https://www.forens-med.ru/book.php? $\mathrm{id}=5201 /$.

13. Калинина Е.Ю., Ягмуров О.Д., Сетко Н.П. Судебно-медицинская экспертиза интоксикаций бытовым и серосодержащим природным газом: пособие для врачей. Москва : Издательский дом Академии 
Естествознания, 2016. 109 c. URL: https://monographies.ru/en/book/ view?id=631/.

14. Luks, Andrew M. et al. Wilderness Medical Society Clinical Practice Guidelines for the Prevention and Treatment of Acute Altitude Illness: 2019 Update. Wilderness \& Environmental Medicine, 2019. Vol. 30, Issue 4, P. S3-S18. URL: https://doi.org/10.1016/j.wem.2019.04.006/.

15. Botezatu G.A., Mutoy G.L. Asphyxia (accidents, casuistry, diseases) / resp. ed. P.I. Maximov. Chisinau : Stinnia, 1983. 96 p.

16. Наказ МОЗ України від 05.06.2019 № 1269 Про затвердження та впровадження медико-технологічних документів зі стандартизації екстреної медичної допомоги. Екстрена медична допомога: догоспітальний етап. Новий клінічний протокол. Київ, 2019. С. 276-279. URL: https://moz.gov.ua/article/ministry-mandates/nakaz-moz-ukraini-vid05062019--1269-pro-zatverdzhennja-ta-vprovadzhennja-medikotehnologichnih-dokumentiv-zi-standartizacii-ekstrenoi-medichnoidopomogi.

\section{Information about authors:} Yekhalov V. V.,

Candidate of Medical Sciences, Associate Professor of the Department of Anesthesiologi, Intensive Care and Emergency States of the Faculty of Postgraduate Education State Institution "Dnipropetrovsk Medical Academy of the Ministry of Health of Ukraine" 9, Vernadsky str., Dnipro, 49044, Ukraine

Khobotova N. V., Candidate of Medical Sciences, Assistant Professor of the Department of ENT Diseases State Institution "Dnipropetrovsk Medical Academy of the Ministry of Health of Ukraine" 9, Vernadsky str., Dnipro, 49044, Ukraine 